\title{
A comparative analysis of energy storage technologies
}

ABSTRACT: The paper describes factors influencing the development of electricity storage technologies. The results of the energy analysis of the electric energy storage system in the form of hydrogen are presented. The analyzed system consists of an electrolyzer, a hydrogen container, a compressor, and a PEMFC fuel cell with an ion-exchange polymer membrane. The power curves of an electrolyzer and a fuel cell were determined. The analysis took the own needs of the system into account, i.e. the power needed to compress the produced hydrogen and the power of the air compressor supplying air to the cathode channels of the fuel cell stack. The characteristics describing the dependence of the efficiency of the energy storage system in the form of hydrogen as a function of load were determined. The costs of electricity storage as a function of storage capacity were determined. The energy aspects of energy accumulation in lithium-ion cells were briefly characterized and described. The efficiency of the charge/discharge cycle of lithium-ion batteries has been determined. The graph of discharge of the lithium-ion battery depending on the current value was presented. The key parameters of battery operation, i.e. the Depth of Discharge (DoD) and the State of Charge (SoC), were determined. Based on the average market prices of the available lithium-ion batteries for the storage of energy from photovoltaic cells, unit costs of electrochemical energy storage as a function of the DoD parameter were determined.

KEYWORDS: energy storage, fuel cells, hydrogen, lithium-ion batteries

\footnotetext{
1 The Poznań University of Technology, the Institute of Electrical Power Engineering, Poznań; e-mail: bartosz. ceran@put.poznan.pl
} 


\section{Introduction}

The current structure of electricity generation in Poland is still based on conventional energy sources, such as lignite- and hard coal-based thermal power plants. However, technological progress and the increasing requirements for the power generation sector have resulted in the introduction of new, alternative energy sources. The newly installed units include small-capacity generating units connected directly to the distribution networks or being part of the recipient's electricity network, which are referred to as distributed energy (Paska 2002).

This direction of change is somewhat forced by regulations introduced by the European Union. They include the climate and energy package (20\% cut in greenhouse gas emissions, $20 \%$ of EU energy from renewables, and $20 \%$ improvement in energy efficiency), and the conclusions on the best available techniques (BAT). Facing the need to introduce changes related to the above-mentioned acts, it seems necessary to look for alternatives to conventional sources of electricity. Despite the fact that the Polish power system is based on these sources, there is an urgent need for new generating capacities due to the decommissioning of old combined cycle units.

The advantages of distributed generation include: relatively low costs of network development, a short investment time frame, increased local energy security, and the generation of energy in the place of its use, which has an impact on reducing transmission losses. The disadvantages include a long period of return on investment and technical problems with integrating the systems (Ceran and Szczerbowski 2013). The use of renewable energy sources, such as wind energy and solar energy, in the distributed generation, is related to another problem that may be crucial for limiting the development of RES. The mentioned problem is the stochastic nature of the operation of these sources, resulting from the variability of wind speed and insolation, as well as the related inability to accurately predict the production capacity.

In order to mitigate the above mentioned problems related to the operation of the power system based on renewable sources with the stochastic nature of operation, energy storage technologies are being used. The development of energy storage technologies makes it possible to shift energy generation from renewable sources from off-peak hours to peak hours. In the case of photovoltaic installations, which are currently developing the most dynamically in Poland, electrochemical batteries, which currently dominate the market, are the most common energy storage device in use.

An alternative to electrochemical energy storage may be the storage of energy in the form of hydrogen. In the paper, the author compared two modern technologies of energy storage characterized by a small size, i.e. lithium-ion batteries and the electrolyzer-fuel cell system with a power of several kilowatts, storing energy in the form of hydrogen. 


\section{The electricity storage in the form of hydrogen}

When it comes to well-known energy storage systems, the PEMFC fuel cell, combined with an electrolyzer and a hydrogen tank (electrolyzer - fuel cell system) is believed to have the biggest potential. It should be noted that improper terminology is often used in the case of some of the discussed electricity storage technologies. For example, in the electrolyzer - fuel cell system, both the electrolyzer and the fuel cell do not store energy, but only convert it. The hydrogen tank is designed to store all of the excess energy; however, this fact is not reflected in the name of the technology. A similar inaccuracy can be observed in the case of pumped storage power plants, where the energy is not stored in the power plant itself, but in the upper reservoir. The block diagram of the system is shown in Fig. 1.

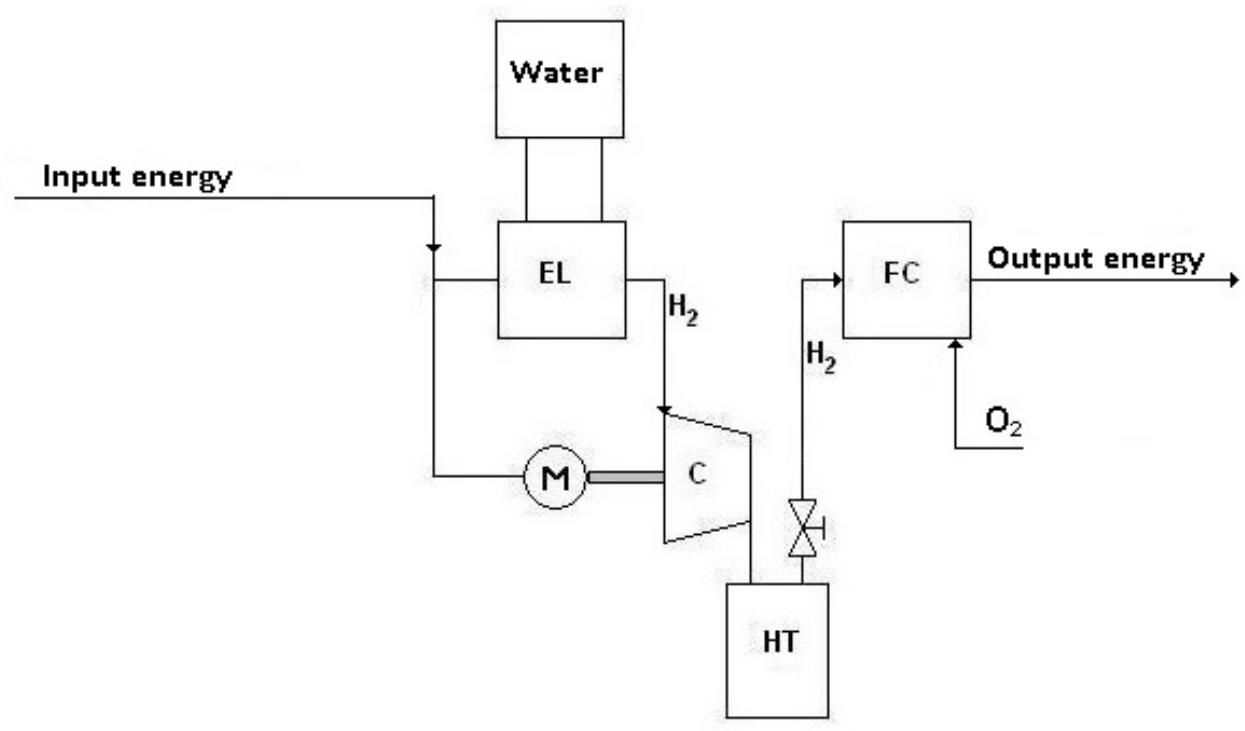

Fig. 1. The block diagram of the energy storage system; electrolyzer - fuel cell:

$\mathrm{El}$ - Electrolyzer, HT - hydrogen container, FC - fuel cell, C - compressor

Rys. 1. Schemat blokowy układu magazynowania energii elektrolizer - ogniwo paliwowe:

El - elektrolizer, HT - zbiornik wodoru, FC - ogniwo paliwowe, C - kompresor

The efficiency of the energy storage system in the form of hydrogen can be described as the product of the efficiency of the hydrogen production process and its consumption during the production of electricity.

$$
\eta_{E l_{-} O P}=\eta_{E l} \cdot \eta_{\text {of the storage system }} \cdot \eta_{O P}(1-\varepsilon)
$$


Where:

$\eta_{E l}$

- the efficiency of converting electricity into chemical energy [\%],

$\eta_{O P}$

- the efficiency of converting chemical energy into electrical energy [\%],

$\eta_{\text {of the storage system }} \quad-$ the efficiency of filling and emptying the hydrogen tank [\%],

$\eta_{o p}$

- the efficiency of fuel cell stack [\%],

$\varepsilon$

- the indicator of own system needs.

In order to determine the amount of hydrogen produced by the electrolyzer and the amount of hydrogen consumed by the fuel cell, the characteristics of $\mathrm{P}=\mathrm{f}\left(\mathrm{V}_{\mathrm{H} 2}\right)$, based on the external characteristics of the electrolyzer and the cell $\mathrm{U}=\mathrm{f}(\mathrm{I})$ (figures 2 and 3 ) were used.

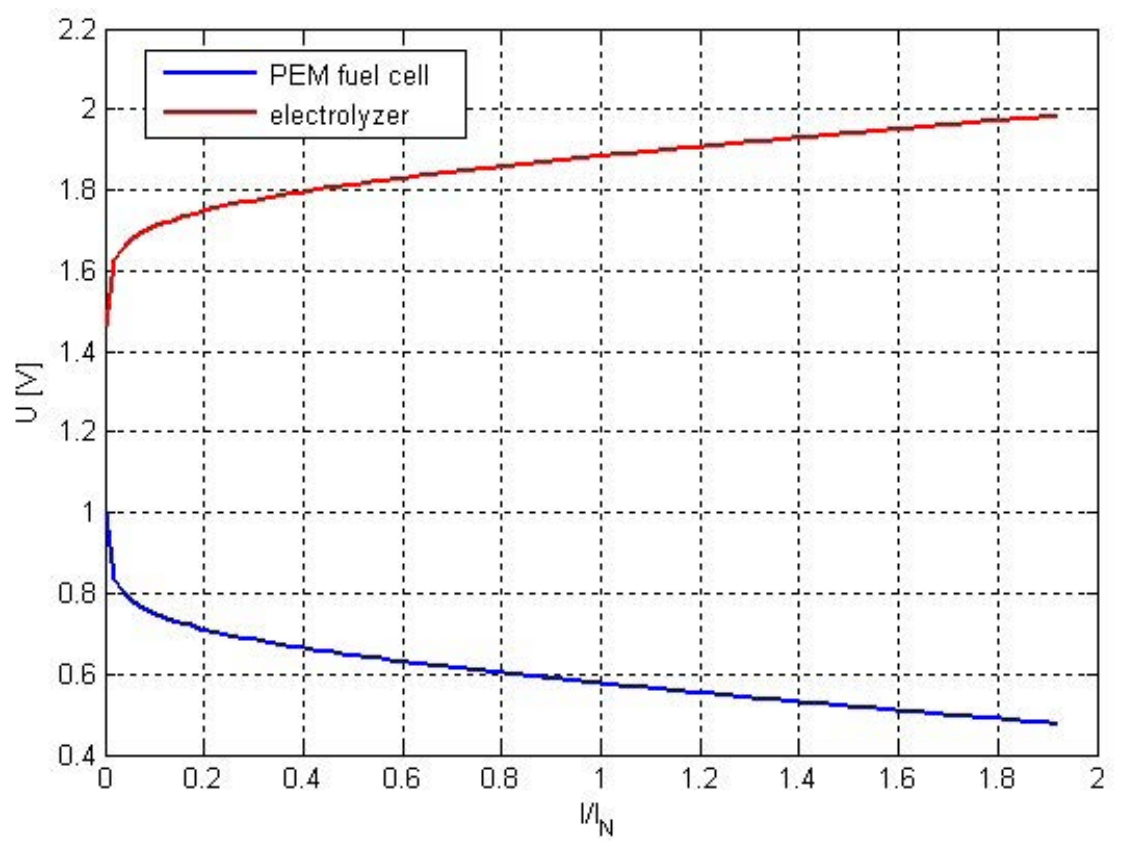

Fig. 2. External characteristics of the electrolyzer and fuel cell

Rys. 2. Charakterystyki zewnętrzne elektrolizera oraz ogniwa paliwowego

In addition to energy losses during the "electrical energy - chemical energy" conversion cycle, the system also requires energy to compress the produced hydrogen to the desired pressure. The latest technology of light pressure vessels equipped with special diaphragms allows for storing hydrogen at a pressure of 700 bar, while the amount of stored gas equals $12 \%$ of the tank's weight.

The power needed to power the compressor, which is the main auxiliary device, can be described by the following formula: 


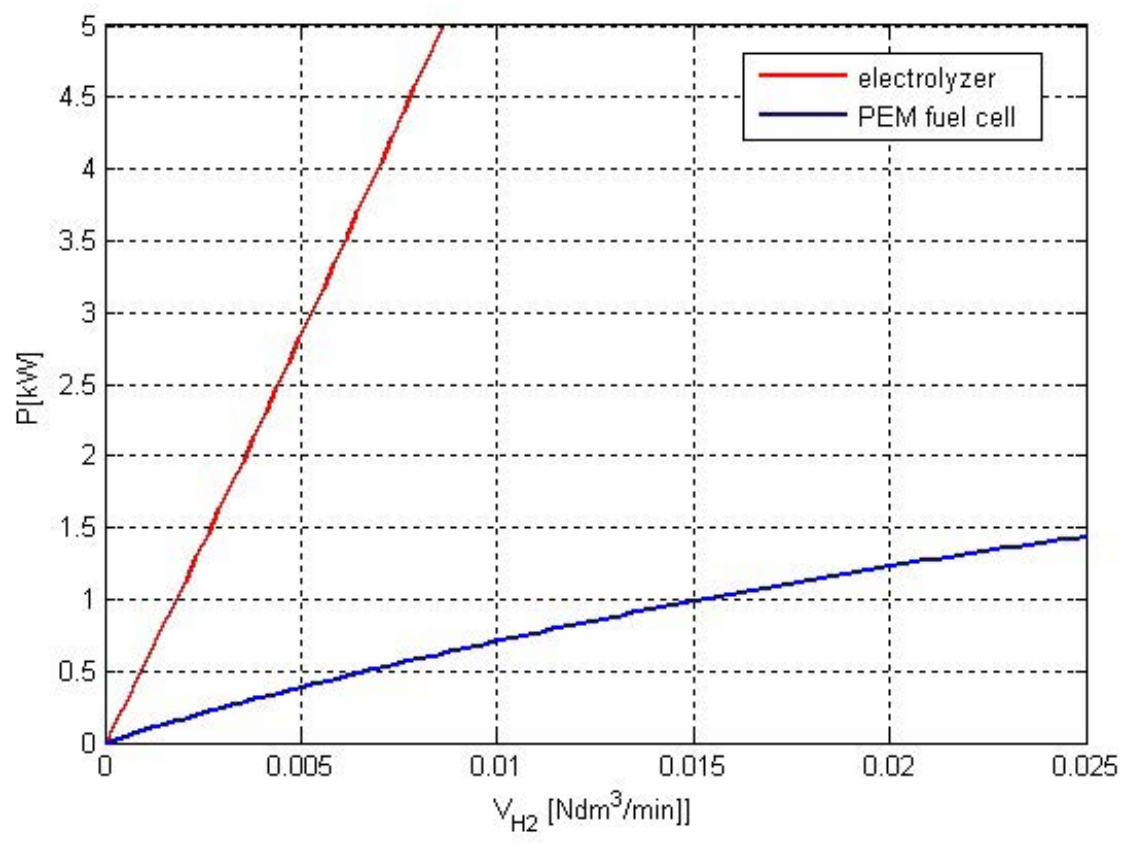

Fig. 3. The characteristics of $P=f\left(V_{H 2}\right)$ - own work

Rys. 3. Charakterystyki $P=f\left(V_{H 2}\right)$ - opracowanie własne

$$
P_{\text {komp }}=m_{H_{2}} \frac{\kappa}{\kappa-1} p_{0} v_{0}\left[\left(\frac{p_{1}}{p_{0}}\right)^{\frac{\kappa-1}{\kappa}}-1\right] \frac{1}{\eta_{i k o m p}} 10^{-3} \quad[\mathrm{~kW}]
$$

Where:

$m_{H 2}$ - the mass flow of hydrogen $[\mathrm{kg} / \mathrm{s}]$,

$\kappa \quad-\quad$ the adiabatic exponent $(\kappa=1.41$ for hydrogen),

$p_{0} \quad-$ the hydrogen pressure before compression [MPa],

$v_{0} \quad-$ the specific volume of hydrogen $\left[\mathrm{Nm}^{3} / \mathrm{kg}\right]$,

$p_{1} \quad-$ te hydrogen pressure after compression,

$\eta_{\text {ikomp }}-$ the internal efficiency of the compressor [MPa].

The hydrogen stream is proportional to the intensity of the electric current according to dependence No. 3 .

$$
m_{H_{2}}=22,42 \cdot \frac{I \cdot n_{\text {cells }}}{2 \cdot F} \mu \quad\left[\frac{\mathrm{kg}}{\mathrm{s}}\right]
$$


Where:

$n_{\text {cells }}-$ the number of individual cells in the stack [-],

$I \quad-$ the current flowing into the electrolyzer [A],

$F \quad-$ Faraday's constant [C/mol],

$\mu \quad-$ the hydrogen density $\left[\mathrm{kg} / \mathrm{Nm}^{3}\right]$.

Based on formulas 2 and 3, a diagram of the energy required to compress hydrogen as a function of the final pressure was developed (Fig. 4).

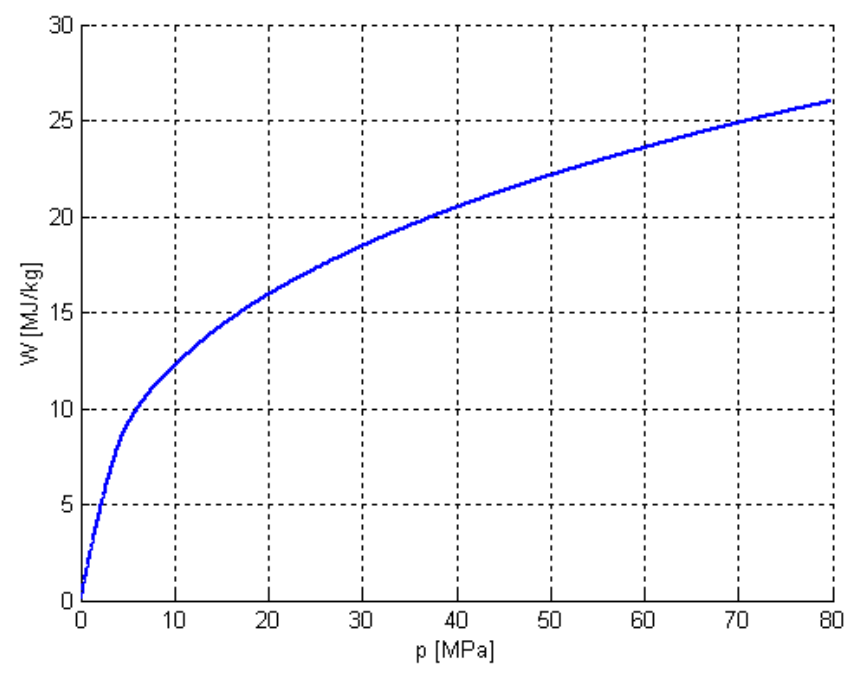

Fig. 4. The energy required to compress $1 \mathrm{~kg}$ of hydrogen as a function of the final pressure (own work)

Rys. 4. Zależność pracy, jaką trzeba wykonać, aby sprężyć 1 kg wodoru w funkcji ciśnienia końcowego

The indicator of own system needs is defined as:

$$
\varepsilon=\frac{P_{p w}}{P_{\text {elstack }}}
$$

Where:

$P_{p w} \quad-$ electricity consumed for own needs of the system.

The air compressor is the most important auxiliary equipment of the fuel cell system. The use of a compressor in fuel cell systems is aimed at increasing the excess air supply $\lambda_{\text {pow }}$ to the cathode channels in order to increase the availability of oxygen in the oxidation reaction regions. The volumetric air stream supplied to the fuel cell system is described by the following formula: 


$$
V_{\text {pow }}=\frac{22,42}{0,21} \cdot \frac{I \cdot n_{\text {cells }} \cdot \lambda_{\text {pow }}}{z \cdot F}\left[\frac{\mathrm{Ndm}^{3}}{\mathrm{~s}}\right]
$$

Where:

$\lambda_{\text {pow }}-$ the coefficient of excess air supplied to the cathode channels of the fuel cell stack.

The power needed to power the compressor can be described by the formula (26):

$$
P_{\text {komp }}=m_{\text {pow }} \frac{\kappa}{\kappa-1} p_{0} v_{0}\left[\left(\frac{p_{1}}{p_{0}}\right)^{\frac{\kappa-1}{\kappa}}-1\right] \frac{1}{\eta_{i k o m p}}[\mathrm{~W}]
$$

Where:

$m_{\text {pow }}-$ the mass flow of air $[\mathrm{kg} / \mathrm{s}]$,

$\kappa \quad-$ the adiabatic exponent,

$p_{0} \quad-$ the air pressure before compression $[\mathrm{Pa}]$,

$v_{0} \quad-$ the specific volume of air $\left[\mathrm{Nm}^{3} / \mathrm{kg}\right]$,

$p_{1} \quad$ - the air pressure after compression [Pa],

$\eta_{i k o m p}-$ the internal efficiency of the compressor.

Based on the dependencies 1-6, the characteristics of the efficiency of energy storage system as a function of hydrogen load were determined (Fig. 5). The efficiency of the charging and discharging cycle of the electrolyzer - fuel cell system is in the range of $25-45 \%$, depending on the load.

\section{The costs of electricity storage in the form of hydrogen}

The costs of energy storage are influenced by the costs of individual system devices, i.e. the costs of the electrolyzer, fuel cell, compressor, water, and the hydrogen tank. Data for economic analysis came from two sources (Bartosik et al. 2016; Chmielniak et al. 2017). Figure 6 shows the cost of electricity storage in the electrolyzer-fuel cell system as a function of storage capacity.

It should be noted that the unit cost of electricity storage $k_{j}$ by the electrolyzer - fuel cell system, in accordance with the "economies of scale", increases with decreasing storage capacity. Currently, the estimated cost of storage of $1 \mathrm{kWh}$ of electricity in the form of hydrogen in a gas storage device with a capacity of $1 \mathrm{MWh}_{\mathrm{H} 2}$ is PLN 1,500 . 


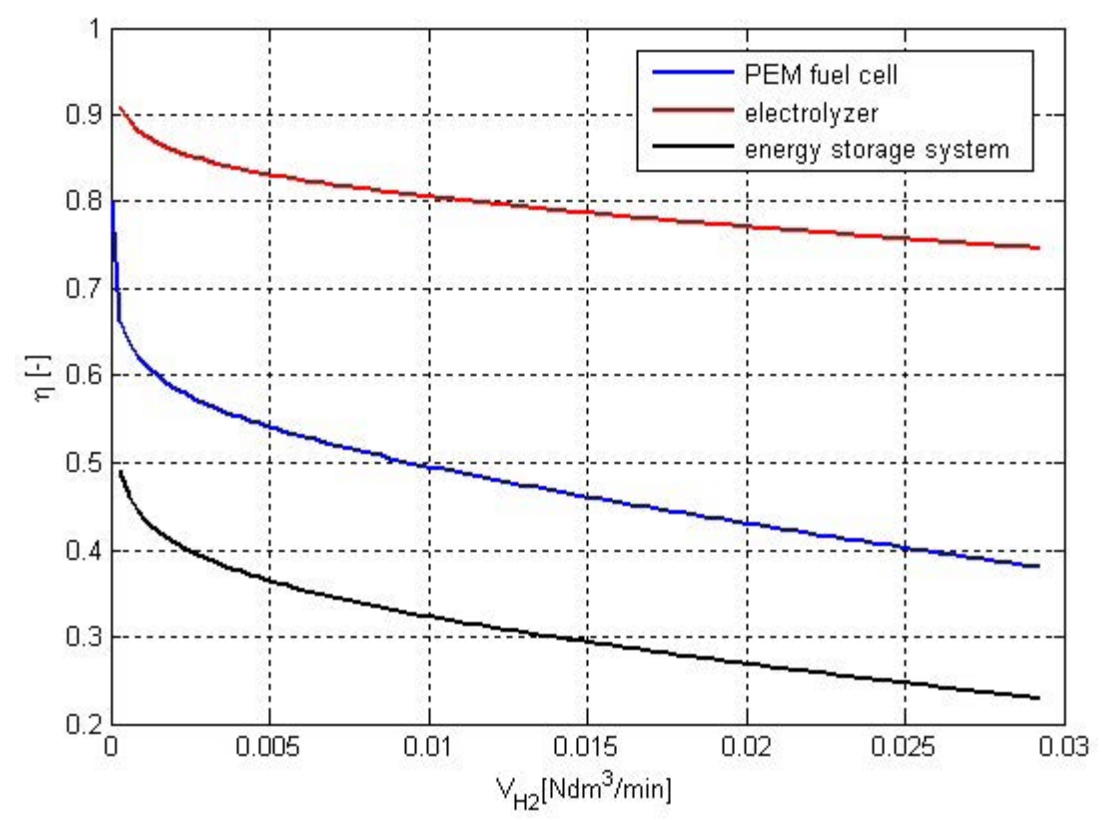

Fig. 5. The efficiency of the fuel cell, electrolyzer, and energy storage system (own work)

Rys. 5. Sprawność ogniwa paliwowego, elektrolizera oraz systemu magazynowania energii

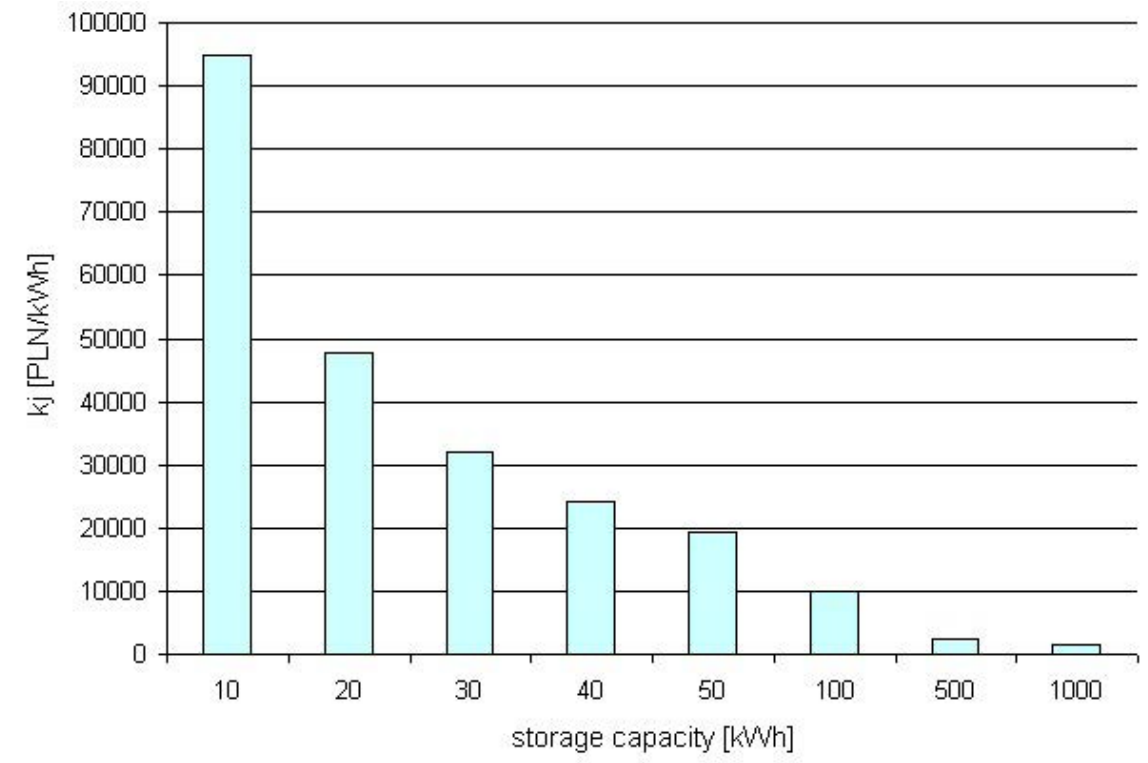

Fig. 6. The cost of electricity storage as a function of storage capacity (own work)

Rys. 6. Koszt magazynowania energii elektrycznej w funkcji pojemności magazynu 


\section{The electricity storage using lithium-ion batteries}

Electrochemical energy storage systems available in the market include lead-acid batteries (AGM and gel type) and lithium-ion batteries. Lithium-ion energy storage technology has a number of advantages in the form of a long cell life and a large capacity per kg of battery but in comparison with lead-acid batteries is still more expensive (Diouf and Pode 2015; Szymański 2017). One of the most important advantages of the lithium-ion batteries is a high energy density compared to the weight of the battery (Czerwiński 2005). For example, for nickel cadmium batteries this parameter is typically $45-80 \mathrm{Wh} / \mathrm{kg}$, for nickel metal hybrid batteries it amounts to $60-120 \mathrm{Wh} / \mathrm{kg}$, while for lithium-ion batteries it is $110-160 \mathrm{Wh} / \mathrm{kg}$. The high energy density of batteries allows significantly reducing the weight of the supplied devices, which is especially important when the storage area is limited.

The efficiency of the lithium-ion battery charging cycle can be described by means of the following formulas:

$$
\begin{gathered}
\eta_{\text {cycle }}=\frac{E_{\text {charge }}}{E_{\text {discharge }}}=\eta_{\text {charge }} \cdot \eta_{\text {discharge }} \\
E_{\text {charge }}=\int_{n}^{t} U(t) \cdot I_{\text {charge }}(t) d t \\
E_{\text {discharge }}=\int_{n}^{t \text { end }} U(t) \cdot I_{\text {discharge }}(t) d t
\end{gathered}
$$

Depending on the charge/discharge current, the efficiency of lithium-ion batteries is in the range of 0.83-0.94 (Toman et al. 2016). The influence of the discharge current on the operation of a lithium-ion battery with a nominal voltage of $12.8 \mathrm{~V}$ is shown in the figure below.

The depth of discharge (DoD) is the percentage of the battery capacity that has been discharged. In turn, the State of Charge (SoC) is the opposite parameter. The depth of discharge affects the battery life; a full discharge can damage the battery. For security reasons, lithium -ion batteries are often equipped with electronic circuit protection against deep battery discharge. Battery manufacturers give battery life data based on the number of charge/discharge cycles. Data sheets contain the number of charge/discharge cycles at a certain depth of discharge $(50-80 \%)$. 


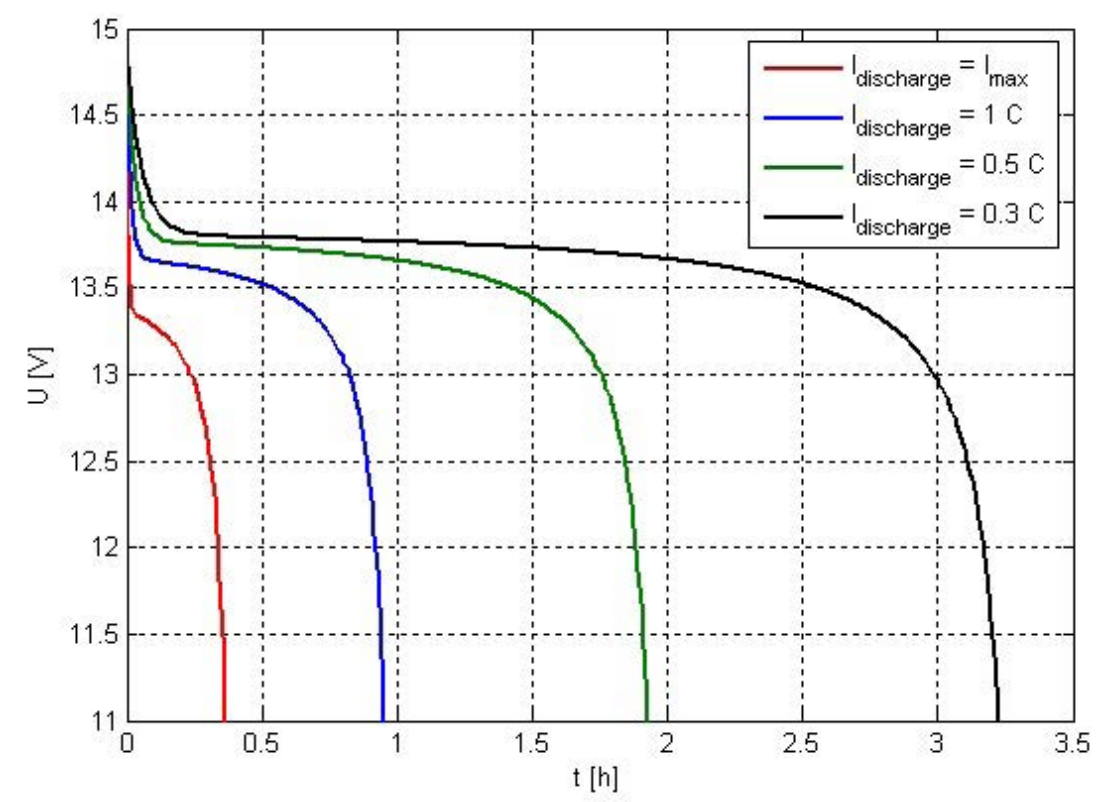

Fig. 7. Discharge characteristics of lithium ion batteries (own work)

Rys. 7. Charakterystyki rozładowania akumulatora litowo jonowego

\section{The costs of electricity storage using lithium-ion batteries}

Table 1 presents the average market prices of the available lithium-ion batteries for energy storage from solar cells. The $k_{j}$ cost, which must be borne to store one $\mathrm{kWh}$ of electricity, was also determined.

TABLE 1. Market prices of lithium-ion batteries

TABELA 1. Ceny rynkowe akumulatorów litowo-jonowych

\begin{tabular}{|c|c|c|c|c|}
\hline $\mathrm{U}[\mathrm{V}]$ & Capacity $[\mathrm{Ah}]$ & Energy $[\mathrm{kWh}]$ & Market price $[\mathrm{PLN}]$ & $k j[\mathrm{PLN} / \mathrm{kWh}]$ \\
\hline 12.8 & 90 & 1152 & 6000 & 5208 \\
\hline 12.8 & 160 & 2048 & 11000 & 5371 \\
\hline 12.8 & 200 & 2560 & 13000 & 5078 \\
\hline 12.8 & 300 & 3840 & 20000 & 5208 \\
\hline
\end{tabular}


The cost of electricity storage given in Table 1 refers to the case when the entire capacity of the battery is charged or discharged, i.e. if the DoD and SoC parameters change their values in the course of operation in the range from $100 \%$ to 0 and from 0 to $100 \%$. Technically, this is not possible due to the impossibility of completely discharging the battery. Fig. 8 shows the average prices for electricity storage, depending on the DoD.

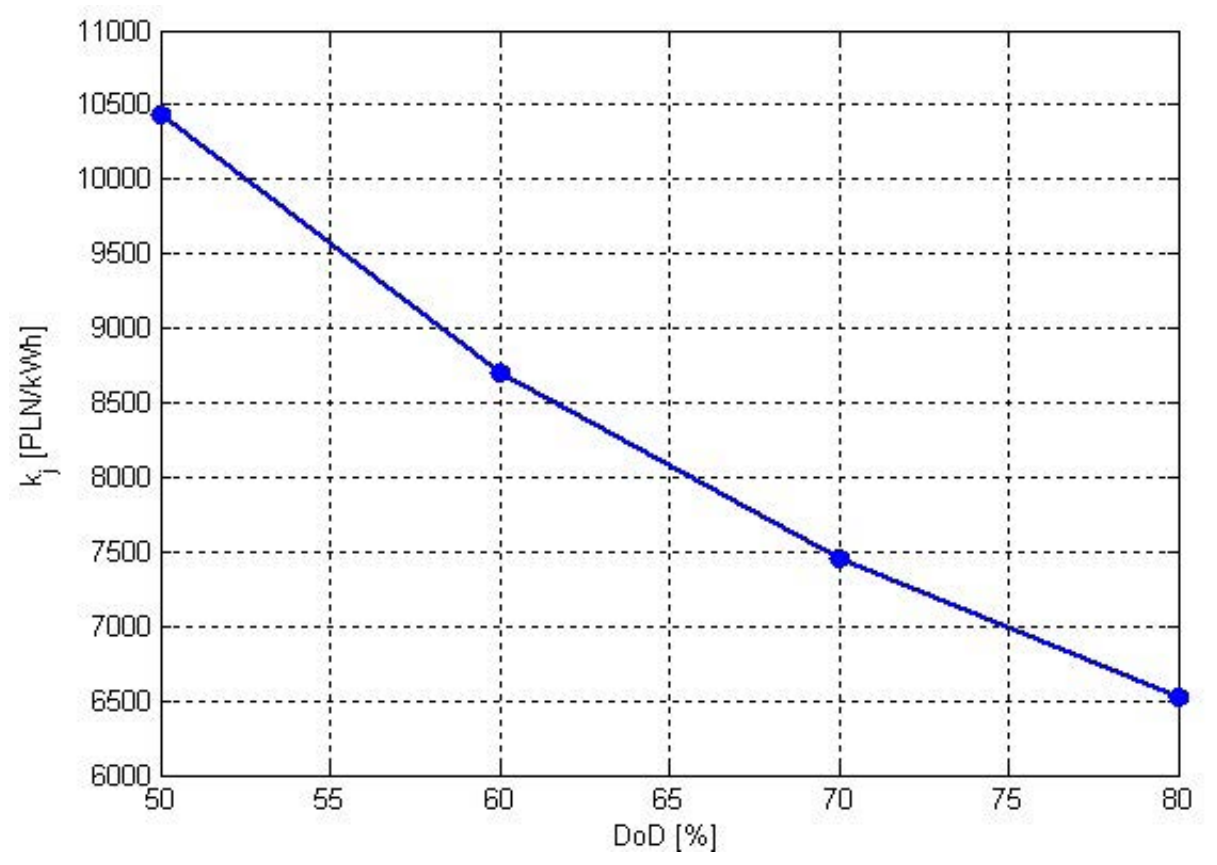

Fig. 8. The cost of energy storage as a function of the depth of battery discharge (own study)

Rys. 8. Koszt magazynowania energii w funkcji głębokości rozładowania akumulatora

Using 50 percent of the battery capacity increases the unit cost of $1 \mathrm{kWh}$ energy storage capacity but extends the life of the battery. The manufacturers claim that the battery will lose approximately $50 \%$ of its storage capacity after 5,000 charge-discharge cycles. In the case of a battery capacity below $80 \%$, this value decreases to 2,500 cycles.

\section{Conclusions}

There is no doubt that the future of renewable energy sources with the stochastic nature of operation will be related to the development and costs of electricity storage technologies. 
The energy analysis has shown that the efficiency of the energy storage system in the form of hydrogen is in the range of $25-45 \%$. Despite a relatively low efficiency of the charging and discharging cycle, the electrolyzer - fuel cell system has a high energy density value of 400$-500 \mathrm{Wh} / \mathrm{kg}$. The need to reduce the storage area has resulted in new technical solutions currently being introduced in the market, in which fuel cell and electrolyzer are replaced with a fuel cell run in reverse mode, the so-called RFC (Reversible Fuel Cell).

As of today, the energy storage costs in the form of hydrogen are too high to think about the widespread use of this technology. The progress in the development of hydrogen energy requires further research and development (Chmielniak et al. 2017; Molenda 2008). It is particularly important to improve the process of electrolysis of water.

Based on the analysis of the costs of energy storage technology using the electrolyzer - fuel cell system it can be stated that large capacity storage systems intended for long-term operation will be more profitable in the case of the reduction of investment outlays for the construction of storage technologies.

Electrochemical batteries are one of the most mature energy storage technologies. Despite this, the continual development of this sector is the reason why increasingly better operating parameters are obtained with increasingly lower investment outlays. The currently used batteries are well suited to their energy storage tasks. However, it should be remembered that these are short-term storage systems and their operation is limited to a few hours.

In the case of long-term production, i.e. the energy produced in the summer and used during the winter months, hydrogen technologies would be a better solution if the investment expenditures were reduced.

\section{References}

BARTOSIK, M. et al. 2016. Storage of electrical energy and hydrogen economy (Magazynowanie energii elektrycznej i gospodarka wodorowa). Przeglad Elektrotechniczny No. 12, pp. 332-340 (in Polish).

CERAN, B. 2014. Operational characteristics of PEMFC fuel cells. (Charakterystyki eksploatacyjne stosu ogniw paliwowych typu PEMFC). Polityka Energetyczna - Energy Policy Journal Vol. 17, Iss. 3, pp. 135-146 (in Polish).

Ceran, B. and SzczerbowsKi, R. 2013. Small scale, distributed power generation based on renewable energy sources - possibilities for development, cost of electricity production, and technical problems (Możliwości rozwoju i problemy techniczne małej generacji rozproszonej opartej na odnawialnych źródtach energii). Polityka Energetyczna - Energy Policy Journal Vol. 16, Iss. 3, pp. 193-204 (in Polish).

CHMiElNiAK, T. et al. 2017. Hydrogen energy - main problems (Energetyka wodorowa - podstawowe problemy). Polityka Energetyczna - Energy Policy Journal Vol. 20, Iss. 3, pp. $55-66$ (in Polish).

CZERWINSKI, A. 2005. Accumulators, batteries, cells (Akumulatory baterie ogniwa). Wydawnictwa komunikacji i łączności (Transport and Communication Publishers), Warsaw (in Polish).

Diouf, B. and Pode, R. 2015. Potential of lithium-ion batteries in renewable energy. Renewable Energy Vol. 76, pp. 375-380. 
MolendA, J. 2008. Hydrogen Energy - Technologies and perspectives. A report of renewable energy sector experts (Energetyka Wodorowa - Technologie i Perspektywy. Raport Ekspertów Sektora OZE) (in Polish).

PASKA, J. 2002. Possibilities of using fuel cells in distributed generation (Możliwości wykorzystania ogniw paliwowych w generacji rozproszonej). Rynek Energii (Energy market), No. 6, pp. 16-23 (in Polish).

SZYMAŃSKI, B. 2017. Photovoltaic installations (Instalacje fotowoltaiczne). Kraków: Wyd. GlobEnergia (in Polish).

TOMAN M. et al. 2016. Li-ion Battery Charging Efficiency. ECS Transactions 74 (1) pp. 37-43.

TOMCZYK P. 2009. Prospects and obstacles of hydrogen economy development (Szanse i bariery rozwoju energetyki wodorowej). Polityka Energetyczna - Energy Policy Journal Vol. 12, Iss. 2/2, pp. 593-606 (in Polish).

\section{Analiza porównawcza technologii magazynowania energii elektrycznej}

\section{Streszczenie}

W referacie opisano czynniki wpływające na rozwój technologii magazynowania energii elektrycznej. Przedstawiono wyniki analizy energetycznej systemu magazynowania energii elektrycznej w postaci wodoru. Analizowany system składa się z elektrolizera, zbiornika wodoru, kompresora, oraz systemu ogniw paliwowych z jonowymienną membraną polimerową PEMFC. Wyznaczono krzywe mocy elektrolizera oraz ogniwa paliwowego. W analizie uwzględniono potrzeby własne systemu, tj. moc potrzebną na sprężenie wyprodukowanego wodoru oraz moc kompresora powietrza dostarczającego powietrze do kanałów katodowych stosu ogniw paliwowych. Wykreślono charakterystykę przedstawiającą zależność sprawności systemu magazynującego energię w postaci wodoru w funkcji obciążenia. Wyznaczono koszty magazynowania energii w postaci wodoru w funkcji pojemności magazynu. Krótko scharakteryzowano oraz opisano energetyczne aspekty akumulacji energii za pomocą baterii litowo-jonowych. Zdefiniowano sprawność cyklu ładowania/rozładowania akumulatorów litowo jonowych. Przedstawiono wykres rozładowania akumulatora litowo jonowego w zależności od wartości prądu. Zdefiniowano parametry charakteryzujące pracę akumulatora tj. głębokość rozładowania DoD (and. Depth of discharge) oraz stan naładowania SoC (ang. State of Charge). Na podstawie średnich cen rynkowych dostępnych akumulatorów litowo jonowych przeznaczonych do magazynowania energii z instalacji fotowoltaicznych wyznaczono jednostkowe koszty elektrochemicznego magazynowania energii elektrycznej w funkcji parametru DoD. 
